\title{
Faktor-Faktor Yang Mempengaruhi Kinerja Bank Devisa Yang Terdaftar Di Bursa Efek Indonesia (2013-2017)
}

\author{
Hartanti \\ Program Studi Manajemen Perpajakan \\ Akademi Manajemen Keuangan BSI Jakarta \\ Jl. Dewi Sartika Raya No.289 Cawang Jakarta Timur \\ hartanti.hti@bsi.ac.id
}

\begin{abstract}
Performance is a tool to evaluate the success of the company in running its business. This study aims to examine the performance factors of Foreign Exchange Banks Listed on the Indonesia Stock Exchange. Performance factors in this study were measured by the ratio of CAR, NPL, LDR, BOPO, GWM while Performance measured by ROA. This study uses quantitative analysis with multiple linear regression model to test the influence of these factors on the performance of foreign exchange banks simultaneously or partially. The results showed that there was a significant and simultaneous influence between $C A R, N P L$, LDR, BOPO, GWM on Foreign Exchange Bank ROA. Coefficient of determination simultaneously CAR, NPL, LDR, BOPO, GWM affect ROA of 83,4\% and the rest influenced by other factors. Partially CAR, NPL and GWM have no significant effect on ROA of Foreign Exchange Bank. while the LDR and BOPO have a negative and significant effect on the ROA of Foreign Exchange Bank.
\end{abstract}

Keywords $\quad C A R, N P L, L D R, B O P O, G W M$, and ROA

\section{PENDAHULUAN}

Hasil kinerja perusahaan merupakan alat evaluasi keberhasilan perusahaan dalam menjalankan usahanya. Semakin baik kinerja perusahaan, kondisi perusahaan juga semakin baik. Hal ini juga berlaku dalam dunia perbankan khususnya bank devisa, semakin baik kinerja bank devisa semakin sehat dan menambah kredibilitas serta kepercayaan pihak-pihak berkepentingan terhadap bank devisa tersebut. Salah satunya adalah investor dalam mengambil keputusan untuk menanamkan modal atau tidaknya kedalam bank tergantung dari kinerja bank devisa tersebut.

Bank Devisa merupakan bank yang dapat melaksanakan kegiatan transaksi ke luar negeri atau yang berhubungan dengan mata uang asing secara keseluruhan, misalnya transfer ke luar negeri, inkaso ke luar negeri, travelers cheque, pembukuan dan pembayaran Letter of Credit $(L / C)$ dan transaksi luar negeri lainnya. Untuk menjadi bank devisa harus memenuhi semua persyaratan yang telah ditetapkan Bank Indonesia. [1]

Kinerja bank devisa dapat dilihat berdasarkan analisa rasio laporan keuangan. Rasio yang digunakanpun bermacam-macam meliputi rasio permodalan, rasio kualitas aset, rasio rentabilitas, rasio likuiditas dan kepatuhan. Rasio permodalan untuk bank devisa digunakan rasio CAR (Capital Adequancy Ratio), pada tahun 2013-2017 rata-rata permodalan bank devisa yang laporan terdaftar di bursa efek Indonesia diatas 8\%, berarti sudah sesuai dengan peraturan yang telah ditetapkan oleh Bank Indonesia sebagai regulator perbankan. Dalam menentukan CAR diperoleh dari modal bank dibanding dengan Aktiva Resiko Menurut Tertimbang. Dalam modal bank terdapat modal inti dan dibagi menjadi berbagi kelompok, BUKU 1 (modal inti dibawah Rp 1 tirliun), BUKU 2 (modal inti Rp 1 tirliun-Rp 10triliun, BUKU 3 (modal inti Rp 10 triliun- Rp50 Triliun), BUKU 4(modal inti diatas Rp 50 Triliun).

Rasio untuk kualitas Aset bisa digunakan Rasio NPL (Non Performing Loan) untuk mengukur tingkat kredit yang bermasalah, untuk rasio ini tidak lebih dari 5\%, apabila lebih dari 5\% akan dilakukan pengawasan dari Bank Indonesia. Rasio rentabilitas untuk mengukur tingkat keuntungan bank digunakan rasio ROA (Return On Aset) dan BOPO (Biaya Operasional terhadap pendapatan operasional), rasio BOPO juga dikelompokkan berdasarkan BUKU (bank umum kelompok usaha), BUKU 1 nilai BOPO maksimal 85\%, BUKU II kisaran 78\%-80\%, BUKU III 70-75\% dan BUKU IV 60\%-65\%. 
Rasio likuiditas untuk mengukur kemampuan bank dalam memenuhi kewajibannya dengan rasio LDR (Loan Deposit Ratio) dan Rasio Kepatuhan dengan GWM (Giro Wajib Minimum) juga tidak boleh kurang dari $5 \%$.

\section{LANDASAN TEORI}

\section{Bank}

Undang-Undang Nomor 10 Tahun 1998 tentang Perbankan yang dimaksud oleh Bank adalah badan usaha yang menghimpun dana dari masyarakat dalam bentuk simpanan dan menyalurkannya ke masyarakat dalam bentuk kredit dan/atau bentuk-bentuk lainnya dalam rangka meningkatkan taraf hidup rakyat banyak.

"Bank adalah badan usaha yang kekayaannya terutama dalam bentuk aset keuangan (financial assets) serta bermotifkan profit dan juga sosial, jadi bukan hanya mencari keuntungan saja". [2]

\section{Jenis Bank}

Jenis Bank ada bermacam-macam, jenis bank menurut status atau kedudukan bank, hal ini menunjukkan kemampuan bank dalam melayani masyarakat dari segi jumlah produk, modal dan kualitas pelayanannya adalah sebagai berikut:

\section{Bank Devisa}

Merupakan bank yang dapat melaksanakan transaksi keluar negeri atau yang berhubungan dengan mata uang asing secara keseluruhan misalnya transfer keluar negeri, inkaso keluar negeri,travellers cheque, pembukaan dan pembayaran letter of credit dan transaksi lainnya. Persyaratan menjadi bank devisa ditentukan oleh Bank Indonesia

2. Bank Non Devisa

Merupakan bank yang belum mempunyai izin untuk melaksanakan transaksi sebagai bank devisa sehingga tidak dapat melaksanakan transaksi seperti halnya Bank Devisa. [3].

\section{Laporan Keuangan}

Laporan keuangan merupakan struktur yang menyajikan posisi keuangan dan kinerja keuangan dalam sebuah entitas.Tujuan umum darilaporan keuangan ini untuk kepentingan umum adalah penyajian informasi mengenai posisi keuangan (financial position), kinerja keuangan (financial performance), dan arus kas (cash flow) dari entitas yang sangat berguna untuk membuat keputusan ekonomis bagi para penggunanya.Untuk dapat mencapai tujuan ini, laporan keuangan menyediakan informasi mengenai elemen dari entitas yang terdiri dari aset, kewajiban, networth, beban, dan pendapatan (termasuk gain dan loss), perubahan ekuitas dan arus kas. Informasi tersebut diikuti dengan catatan,akan membantu pengguna memprediksi arus kas masa depan. [4]

Laporan keuangan itu terdiri dari neraca dan perhitungan laba-rugi serta laporan perubahan ekuitas. Neraca menunjukkan/menggambarkan jumlah aset, kewajiban dan ekuitas dari suatu perusahaan pada tanggal tertentu. Sedangkan perhitungan (laporan) laba-rugi memperlihatkan hasil-hasil yang telah dicapai oleh perusahaan serta beban yang terjadi selama periode tertentu, dan laporan perubahan ekuitas menunjukkan sumber dan penggunaan atau alasan-alasan yang menyebabkan perubahan ekuitas perusahaan. [5]

\section{Rasio keuangan}

\section{a. CAR (Capital Adequancy Ratio)}

Car merupakan faktor penting untuk perusahaan semakin besar car perusahaan akan semakin baik kinerja perusahaan, karena perusahaan dalam kondisi aman karena didukung dengan modal yang besar.

Capital adequacy ratio (CAR) adalah kemampuan bank untuk menutup risiko kerugian dari aktivitas yang dilakukannya dan kemampuan bank dalam mendanai kegiatan operasionalnya". [6]. Menurut UU perbankan 
NOMOR: 3/21/PBI/2001, menetapkan bahwa bank untuk CAR minimal $8 \%$, apabila kurang akan dibawah pengawasan Bank Indonesia

\section{$\mathrm{CAR}=\underline{\text { Modal }(\text { modal inti }+ \text { modal pelengkap) }} \times 100$}

ATMR

\section{b. NPL (Non Performing Loan)}

Rasio Non Performing Loan adalah perbandingan antara jumlah kredit yang diberikan dengan tingkat kolektibilitas 3 sampai 5 dibandingkan dengan total kredit yang diberikan oleh bank. Semakin besar tingkat NPL menunjukkan bahwa bank tersebut tidak profesional dalam pengelolaan kreditnya, sekaligus memberikan indikasi bahwa tingkat risiko atas pemberian kredit pada bank tersebut cukup tinggi searah dengan tingginya NPL yang dihadapi bank [7].

Rasio ini dapat dirumuskan sebagai berikut (Sesuai SE No.6/23/DPNP Tanggal 31 Mei 2004) :

$$
\mathrm{NPL}=\frac{\text { Kredit bermasalah }}{\text { Total Kredit }} \times 100 \%
$$

\section{c. LDR (Loan to Deposit Ratio)}

Rasio likuiditas dapat diukur menggunakan loan to deposit ratio (LDR). LDR adalah perbandingan antara total kredit yang telah diberikan oleh bank dengan total dana"Loan to Deposit Ratio merupakan rasio untuk mengukur komposisi jumlah kredit yang diberikan dibandingkan dengan jumlah dana masyarakat dan modal sendiri yang digunakan.” [8]

Rasio Loan to Deposit Ratio ini dapat dihitung dengan rumus sebagai berikut [9]:

$$
\text { LDR }=\text { Total Loan } / \text { Total Deposit }+ \text { Equity }
$$

\section{d. GWM (Giro Wajib Minimum)}

GWM adalah jumlah dana minimum yang wajib dipelihara oleh Bank yang besarnya ditetapkan oleh Bank Indonesia sebesar persentase tertentu dari DPK.

GWM Primer adalah simpanan minimum yang wajib dipelihara oleh Bank dalam bentuk saldo Rekening Giro pada Bank Indonesia yang besarnya ditetapkan oleh Bank Indonesia sebesar persentase tertentu dari DPK. Sedang GWM sekunder adalah cadangan minimum yang wajib dipelihara oleh Bank berupa Sertifikat Bank Indonesia, Sertifikat Deposito Bank Indonesia, Surat Berharga Negara dan/atau Excess Reserve, yang besarnya ditetapkan oleh Bank Indonesia sebesar persentase tertentu dari DPK.

Pemenuhan GWM dalam Rupiah sebagaimana dimaksud dalam Pasal 2 ayat (2) ditetapkan sebagai berikut:

a. GWM Primer dalam Rupiah sebesar 8\% (delapan persen) dari DPK dalam Rupiah.

b. GWM Sekunder dalam Rupiah dengan pengaturan sebagai berikut:

1. sebesar 2,5\% (dua koma lima persen) dari DPK dalam Rupiah sampai dengan tanggal 30 September 2013;

2. sebesar 3\% (tiga persen) dari DPK dalam Rupiah sejak tanggal 1 Oktober 2013 sampai dengan tanggal 31 Oktober 2013;

3. sebesar 3,5\% (tiga koma lima persen) dari DPK dalam Rupiah sejak tanggal 1 November 2013 sampai dengan tanggal 1 Desember 2013; dan

4. sebesar 4\% (empat persen) dari DPK dalam Rupiah sejak tanggal 2 Desember 2013. [10]

\section{e. BOPO (Biaya Operasional Terhadap Pendapatan Operasional)}

Rasio BOPO digunakan untuk mengukur tingkat efisiensi dan kemampuan bank dalam melakukan kegiatan operasinya. Mengingat kegiatan utama bank pada prinsipnya adalah bertindak sebagai perantara, yaitu 
menghimpun dan menyalurkan dana masyarakat, maka biaya dan pendapatan operasional bank didominasi oleh biaya bunga dan hasil bunga. Setiap peningkatan biaya operasional akan berakibat pada berkurangnya laba sebelum pajak yang pada akhirnya akan menurunkan laba atau profitabilitas (ROA) bank yang bersangkutan [9]

Biaya operasional merupakan biaya yang dikeluarkan oleh bank dalam rangka menjalankan aktivitas usaha pokoknya (seperti biaya bunga, biaya tenaga kerja, biaya pemasaran, dan lain-lain). Pendapatan operasional merupakan pendapatan utama bank yaitu pendapatan bunga yang diperoleh

dari penempatan dana dalam bentuk kredit dan penempatan operasi lainnya [11]

Menurut Surat Edaran Bank Indonesia Nomor 6/23/ DPNP tanggal 31 Mei 2004, rumus rasio BOPO adalah: Biaya operasional $\times 100 \%$

Pendapatan operasional

\section{f. ROA (Return On Asset)}

ROA menunjukan kemampuan perusahaan dengan mengunakan seluruh aktiva yang dimiliki untuk menghasilkan laba setelah pajak. [12]

$R O A$ adalah kemampuan perusahaan dalam memanfaatkan aktivanya untuk memperoleh laba. Rasio ini mengukur tingkat kembalian investasi yang telah dilakukan oleh perusahaan dengan menggunakan seluruh dana (aktiva) yang dimilikinya. Rasio ini dapat diperbandingkan dengan tingkat bunga bank yang berlaku. Rumus yang digunakan untuk menghitung rasio $R O A$, adalah [13]:

$$
R O A=\frac{\text { Laba Bersih }}{\text { Total Aktiva }} \times 100 \%
$$

\section{METODE PENELITIAN}

Penelitian ini bertujuan untuk meneliti faktor-faktor yang mempengaruhi kinerja bank devisa periode 2013-2017. Data yang digunakan adalah data sekunder, yaitu data laporan keuangan tahunan dari Bank Devisa periode 2013-2017. Sampel bank yang digunakan adalah bank Devisa yang laporan keuangannya tercatat di bursa efek Indonesia dan pada bulan April 2018 sudah melaporkan laporan keuangan tahunan 2017. Sumber data diperoleh dari web www.idx.co.id dan data merupakan data time series yang di pooledkan.

Data dalam penelitian ini adalah data rasio keuangan Capital Adequacy Ratio (CAR), Non Performing Loan (NPL), Loan Deposit Ratio (LDR), Giro Wajib Minimum (GWM), Biaya Operasional terhadap pendapatan Operarional (BOPO) dan Return On Asset (ROA). Adapun yang menjadi variabel InDependent adalah CAR $\left(\mathrm{X}_{1}\right)$, NPL $\left(\mathrm{X}_{2}\right)$, LDR $\left(\mathrm{X}_{3}\right)$, GWM $\left(\mathrm{X}_{4}\right)$, BOPO $\left(\mathrm{X}_{5}\right)$ dan variabel Dependentnya adalah ROA (Y). Data diolah dengan softwere SPSS versi 21. Data tersebut terlebih dahulu dilakukan pengujian asumsi klasik yaitu uji normalitas, uji linieritas, uji multikolinieritas dan heterokadisitas. Setelah itu dianalisis dengan model regresi linier berganda untuk mencari pengaruh secara simultan dan regresi sederhana untuk parsial.

\section{PEMBAHASAN}

\section{Sampel Penelitian}

Sampel yang digunakan dalam penelitian ini adalah data laporan keuangan (2013-2017) bank devisa yang terdaftar di bursa efek Indonesia yang sudah dilaporkan sampai bulan April 2018, sebagai berikut:

Tabel 1. Sampel Bank Devisa

\begin{tabular}{|c|l|}
\hline NO & Nama Bank \\
\hline 1 & Bank BRI \\
\hline 2 & Bank BCA \\
\hline 3 & Bank Danamon \\
\hline 4 & Bank CIMB Niaga \\
\hline 5 & Bank BNI \\
\hline 6 & Bank Mega \\
\hline 7 & Bank NISP \\
\hline 8 & Bank SDRA \\
\hline
\end{tabular}

Sumber: idx.go.id 


\section{Uji Asumsi Klasik}

a. Uji Normalitas

Hasil dari uji kolmogorov-simorrnov Asymp Sig (2-tailed) sebesar 0,144. Hasil tersebut menunjukkan lebih besar dari signifikan $0,05(0,144>0,05)$ berarti data berdistribusi normal.

b. Uji Heterokadisitas

Hasil dari uji glejster untuk rasio CAR, NPL, LDR, GWM, BOPO dan ROA menunjukkan signifikansi lebih besar dari 0,05. Hal ini berarti data rasio CAR, NPL, LDR, GWM, BOPO dan ROA keuangan bank devisa tidak bermasalah dengan heterokadisitas sehingga bisa dilanjutkan untuk penelitian

c. Uji Multikolinieritas

Hasil dari collienarity statistics untuk rasio CAR, NPL, LDR, GWM, BOPO dan ROA menunjukkan nilai VIF $<10$, sehingga penelitian ini terbebas dari gejala multikolinieritas

d. Uji Linieritas

Uji Linieritas dalam penelitian ini menggunakan diagram scater plot seperti dibawah ini:

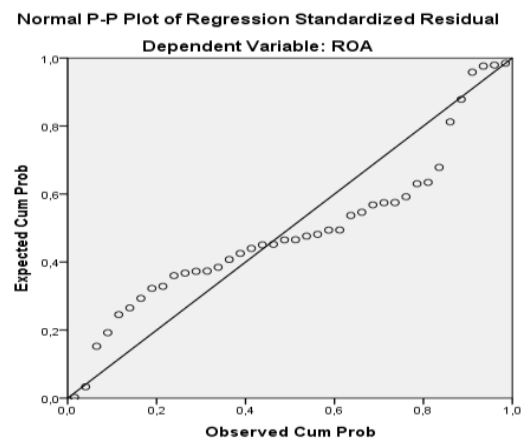

Gambar 1: Plot Garis Antar Variabel (Normal P-P)

Sumber: hasil pengolahan data (2018)

Berdasarkan gambar 1 menunjukkan bahwa gambar plot tersebut titik-titik plot masih mengikuti garis pitline, sehingga penelitian ini data nya linier

\section{Analisis Pengaruh secara Simultan antara CAR, NPL, LDR, LDR, GWM, BOPO terhadap ROA Bank Devisa}

Hipotesa dari secara simultan pengaruh CAR, NPL, LDR, GWM, BOPO terhadap ROA adalah sebagai berikut:

Ho= Tidak ada pengaruh simultan dan signifikan antara CAR, NPL, LDR, GWM, BOPO dengan ROA

$\mathrm{Ha}=$ Ada Pengaruh simultan dan signifikan antara antara CAR, NPL, LDR, GWM, BOPO dengan ROA Hasil pengujian hipotesa bisa dilihat dari hasil uji statistik sebagai berikut:

Tabel 2. Model Summary

Model Summary ${ }^{\mathrm{b}}$

\begin{tabular}{|c|c|c|c|c|c|c|c|c|c|c|}
\hline \multirow[t]{2}{*}{ Model } & \multirow[t]{2}{*}{$\mathrm{R}$} & \multirow[t]{2}{*}{ R Square } & \multirow{2}{*}{$\begin{array}{l}\text { Adjusted } \\
\text { R Square }\end{array}$} & \multirow{2}{*}{$\begin{array}{c}\text { Std. Error } \\
\text { of the } \\
\text { Estimate }\end{array}$} & \multicolumn{5}{|c|}{ Change Statistics } & \multirow{2}{*}{$\begin{array}{l}\text { Durbin- } \\
\text { Watson }\end{array}$} \\
\hline & & & & & $\begin{array}{l}\text { R Square } \\
\text { Change }\end{array}$ & F Change & $\mathrm{df} 1$ & $\mathrm{df} 2$ & $\begin{array}{c}\text { Sig. F } \\
\text { Change }\end{array}$ & \\
\hline 1 &, $925^{\mathrm{a}}$ &, 856 & 834 & ,50226 & ,856 & 40,259 & 5 & 34 & ,000 & 1,325 \\
\hline
\end{tabular}

a. Predictors: (Constant), GWM, LDR, CAR, NPL, BOPO

b. Dependent Variable: ROA

sumber : Hasil penelitian (2018) 
Berdasarkan gambar 2 menunjukan tingkat signifikansi sebesar 0,000 atau kurang dari $5 \%$ dan R square change menunjukkan 0,856. Hal ini berarti bahwa CAR, NPL, LDR, BOPO dan GWM berpengaruh secara simultan dan signifikan terhadap ROA (Ha diterima). Sedangkan besarnya pengaruh CAR, NPL, LDR, BOPO dan GWM terhadap ROA sebesar 0,856 atau 85,6\% sedangkan sisanya dipengaruhi faktor yang lain.

\section{Analisis Parsial antara CAR, NPL, LDR, GWM, BOPO terhadap ROA pada Bank Devisa}

Hipotesa dari secara parsial pengaruh CAR, NPL, LDR, GWM, BOPO terhadap ROA adalah sebagai berikut:

$\mathrm{Ho}=$ Tidak ada Pengaruh secara parsial dan signifikan antara CAR, NPL, LDR, GWM, BOPO dengan ROA

$\mathrm{Ha}=$ Ada Pengaruh secara parsial signifikan antara antara CAR, NPL, LDR, GWM, BOPO dengan ROA

Untuk menguji hipotesa tersebut dilakukan pengujian dengan uji statistik, dengan hasil sebagai berikut

Tabel 3. Uji parsial antara CAR,NPL,LDR,GWM dan BOPO terhadap ROA

Coefficients $^{\mathrm{a}}$

\begin{tabular}{|c|c|c|c|c|c|c|}
\hline \multicolumn{2}{|r|}{ Model } & \multicolumn{2}{|c|}{ Unstandardized Coefficients } & \multirow{2}{*}{$\begin{array}{c}\begin{array}{c}\text { Standardized } \\
\text { Coefficients }\end{array} \\
\text { Beta }\end{array}$} & \multirow[t]{2}{*}{$\mathrm{t}$} & \multirow[t]{2}{*}{ Sig. } \\
\hline & & $\mathrm{B}$ & Std. Error & & & \\
\hline \multirow{6}{*}{1} & (Constant) & 12,781 & 1,506 & & 8,489 & $\overline{, 000}$ \\
\hline & CAR &,- 017 & ,029 &,- 046 &,- 585 &, 562 \\
\hline & NPL &, 089 &, 121 &, 068 &, 730 & , 470 \\
\hline & LDR &,- 018 & ,006 &,- 228 & $-3,279$ &, 002 \\
\hline & BOPO &,- 103 &, 011 & $-1,059$ & $-9,442$ & 000 \\
\hline & GWM &,- 092 & 073 &,- 087 & $-1,263$ & ,215 \\
\hline
\end{tabular}

a. Dependent Variable: ROA

Sumber: Hasil penelitian (2018)

Berdasarkan tabel 3 uji parsial dengan uji statistik hasilnya sebagai berikut:

1. Pengaruh CAR terhadap ROA pada Bank Devisa

Berdasarkan uji statistik pada tabel 3 menunjukkan nilai standardized Coefficients negatif 0,46 dan tingkat signifikansi sebesar 0,562 sehingga CAR tidak berpengaruh secara parsial dan siginifikan terhadap ROA (Ho diterima). Hal tersebut sesuai dengan penelitian yang dilakukan Mawardi menyatakan bahwa CAR tidak berpengaruh terhadap ROA, walaupun nilai CAR tinggi tetap tidak mempengaruhi tingkat ROA nya tinggi atau rendah. [14]

2. Pengaruh NPL terhadap ROA pada Bank Devisa

Berdasarkan uji statistik pada tabel 3 menunjukkan nilai standardized Coefficients positif 0,68 dan tingkat signifikansi sebesar 0,472, sehingga NPL tidak berpengaruh secara parsial dan siginifikan terhadap ROA (Ho diterima). NPL menunjukkan kredit bermasalah semakin kecil nilai NPL tidak mempengaruhi besarnya ROA pada Bank Devisa

3. Pengaruh LDR terhadap ROA pada Bank Devisa

Berdasarkan uji statistik pada tabel 3 menunjukkan nilai standardized Coefficients negatif 0,288 dan tingkat signifikansi sebesar 0,002 sehingga LDR berpengaruh secara parsial negatif dan siginifikan terhadap ROA (Ha diterima). Apabila tingkat likuiditas nya tinggi maka akan berpengaruh secara negatif terhadap ROA (kondisi ROA sebaliknya) Hal ini sesuai dengan penelitian yang dilakukan oleh Werdanintyas (2005) menunjukkan bahwa Loan to Deposit Ratio (LDR) berpengaruh negatif signifikan terhadap Return On Asset (ROA) [9]

4. Pengaruh BOPO terhadap ROA pada Bank Devisa

Berdasarkan uji statistik pada tabel 3 menunjukkan nilai standardized Coefficients negatif 1,059 dan tingkat signifikansi sebesar 0,000 sehingga BOPO berpengaruh secara parsial negatif dan siginifikan terhadap ROA (Ha diterima). Apabila tingkat BOPO nya tinggi maka akan berpengaruh secara negatif terhadap ROAnya 
(kondisi ROA sebaliknya). Hal ini didukung oleh penelitian lainnya menyatakan bahwa Biaya Operasional/PendapatanOperasional (BOPO) berpengaruh negatif signifikan terhadap Return On Asset (ROA). [14]

5. Pengaruh GWM terhadap ROA pada Bank Devisa

Berdasarkan uji Berdasarkan uji statistik pada tabel 3 menunjukkan nilai standardized Coefficients negatif 0,87 dan tingkat signifikansi sebesar 0,215 , sehingga CAR tidak berpengaruh secara parsial dan siginifikan terhadap ROA (Ho diterima).

\section{Analisis Persamaan Regresi Antara CAR, NPL, LDR, LDR, GWM, BOPO terhadap ROA Bank Devisa}

Hipotesa dari persamaan regresi pengaruh antara CAR, NPL, LDR, GWM, BOPO terhadap ROA adalah sebagai berikut:

$\mathrm{Ho}=$ Tidak ada persamaan regresi yang signifikan antara CAR, NPL, LDR, GWM, BOPO dengan ROA

$\mathrm{Ha}=$ Ada persamaan regresi yang signifikan signifikan antara antara CAR, NPL, LDR, GWM, BOPO dengan ROA

Untuk menguji hipotesa bisa diuji dengan uji statistik sebagai berikut

Tabel 4. Uji Anova

ANOVA ${ }^{a}$

\begin{tabular}{|rl|r|r|r|r|r|}
\hline Model & & Sum of Squares & Df & Mean Square & F & Sig. \\
\hline \multirow{2}{*}{1} & Regression & 50,780 & 5 & 10,156 & 40,259 &, $000^{\mathrm{b}}$ \\
& Residual & 8,577 & 34 &, 252 & & \\
& Total & 59,357 & 39 & & & \\
\hline
\end{tabular}

a. Dependent Variable: ROA

b. Predictors: (Constant), GWM, LDR, CAR, NPL, BOPO

sumber: Hasil penelitian (2018)

Berdasarkan tabel 4. Uji anova menunjukkan tingkat signifikansi sebesar 0,000 , hal ini berarti ada persamaan regresi signifikan antara CAR, NPL, LDR, GWM, BOPO dengan ROA (Ha diterima) karena hasil signifikannya kurang dari 0,05

Berdasarkan tabel 3 persamaan regresi dalam penelitian ini adalah $\hat{\mathrm{Y}}=12,781-0,017 x_{1}+0,089 x_{2}+-0,018 x_{3}+-$ $0,103 x_{4}+-0,092 x_{5}$ e. Hal ini berarti dari konstanta atau nilai murni ROA tanpa dipengaruhi faktor lain pada penelitian diatas sebesar 12,781 .

\section{Kesimpulan}

Berdasarkan hasil pembahasan, kesimpulan dari penelitian ini adalah:

1. CAR, NPL, LDR, GWM, BOPO secara simultan berpengaruh signifikan terhadap ROA pada Bank Devisa dan CAR, NPL, LDR, GWM, BOPO berpengaruh bersama-sama terhadap ROA Bank Devisa sebesar 85,6\% dan sisanya dipengaruhi oleh faktor lainnya

2. CAR tidak berpengaruh signifikan terhadap ROA Bank Devisa

3. NPL tidak berpengaruh signifikan terhadap ROA Bank Devisa

4. LDR berpengaruh negatif dan signifikan terhadap ROA Bank Devisa

5. BOPO berpengaruh negatif dan signifikan terhadap ROA Bank Devisa

6. GWM berpengaruh negatif dan signifikan terhadap ROA Bank Devisa

\section{Daftar pustaka}

[1]Triandaru, Sigit dan Totok Budisantoso. 2008. Bank dan Lembaga Keuangan Lain. Jakarta: Salemba Empat.

[2]Hasibuan, Malayu S.P. 2011. Dasar-dasar perbankan. Jakarta: Bumi Aksara 
[3] Kasmir, 2003, Dasar-Dasar Perbankan. Jakarta :PT. Raja Grafindo Persada

[4]Ikatan Akuntan Indonesia. 2012. Standar Akuntansi Keuangan. Jakarta: IAI

[5] Munawir. 2010. Analisis Laporan Keuangan. Edisi 4. Yogyakarta: Liberty

[6]Mokoagow SW, Misbach F. 2015. Faktor-Faktor Yang Mempengaruhi Profitabilitas Bank Umum Syariah Di Indonesia. EBBANK

[7]Riyadi, Selamet. 2006. Banking Asset and Liability Management, edisi ketiga. Jakarta: Fakultas Ekonomi Universitas Indonesia.

[8]Kasmir. 2012. Analisis Laporan Keuangan. Jakarta: Rajawali Pers.

[9]Dendawijaya, Lukman, 2005, Manajemen Perbankan, Penerbit Ghalia Indonesia.

[10]Almilia, Luciana Spica dan Winny Herdiningtyas, 2005, Analisis Rasio CAMEL Terhadap Prediksi Kondisi Bermasalah Pada Lembaga Perbankan Perioda 2000-2002, Jurnal Akuntansi dan Keuangan, Vol.7, No. 2.

[11]Sudana, I Made (2011). Manajemen Keungan Perusahaan, Teori dan Prktik. Jakarta: Erlangga.

[12]Peraturan Bank indonesia Nomor 15/7/PBI/2013 tentang perubahan kedua atas peraturan bank Indonesia nomor 12/19/PBI/2010 tentang giro wajib minimum bank umum pada bank indonesia dalam rupiah dan valuta asing,

[13]Rivai, Veithizal, Sofyan Basri, Sarwono Sudarto, Afandy Permata Veithzal. 2013. Commercial Bank Manajemen Perbankan Dari Teori Ke praktik. Jakarta: PT Raja Grafindo Persada

[14]Mawardi, Wisnu. 2004. Analisis Faktor yang Mempengaruhi Kinerja Bank Umum di Indonesia. Tesis. Magister Manajemen, Universitas Diponegoro Semarang. 